\title{
Reconfiguring domesticity? \\ White women and the Second World War in Southern Rhodesia
}

\author{
Ushehwedu Kufakurinani and Pius Nyambara*
}

\begin{abstract}
This article examines the impact of the Second World War on white/Western women in Southern Rhodesia and looks at the nature of their contribution towards the war effort. In many ways, the war reconfigured their domesticity. While the Southern Rhodesian state and society held and promoted the home as the ideal occupation for women, this war, as it did in many other places, especially in the industrialised world, saw women increasingly moving outside the home. However, this did not necessarily mean a deviation from the dominant domestic ideology, but rather a reconfiguration of this ideology because women's contributions were channelled towards domestic oriented and related occupations. Thus the home frontiers had simply expanded to coincide with those of the colony and the empire at large. Organisations were set up to harness women's labour power and schemes were commenced with the same objective. These changes were bound to bring about friction at a number of levels because they radically affected the status quo.
\end{abstract}

Key words: gender studies; white women and empire; domesticity; Southern Rhodesia; Second World War.

\section{Opsomming}

Hierdie artikel bestudeer die uitwerking van die Tweede Wêreldoorlog op wit/Westerse vroue in Suid-Rhodesië, sowel as die aard van hul bydrae tot die oorlog. Die oorlog het op velerlei wyses hul huislike bestaan omvorm. Alhoewel die SuidRhodesiese staat en samelewing, veral ten tyde van die oorlog, tuisteskepping as die vrou se ideale ambag voorgehou het, het vroue in Suid-Rhodesië, soos vele ander in veral die industriële lande, toenemend hul huishoudings agtergelaat. Dit het egter nie beteken dat daar van die heersende huislike ideologie afgewyk is nie. Inteendeel, dié

\footnotetext{
* Ushehwedu Kufakurinani is a senior lecturer at the University of Zimbabwe. He teaches in the Department of Economic History and his main areas of interest are in gender and empire; gender and migration; and the economic history of Zimbabwe. Pius Nyambara is a senior lecturer at the University of Zimbabwe and teaches in the Department of Economic History. His field of speciality is peasant and agrarian studies in particular and the economic history of Zimbabwe in general.
}

\section{How to cite this article:}

U. Kufakurinani and P. Nyambara, "Reconfiguring domesticity? White women and the Second World War in Southern Rhodesia", Historia 60, 2, November 2015, pp 132-159. http://dx.doi.org/10.17159/2309-8392/2015/v60n2a7

Copyright:

(C) 2015. The Author(s). Published under a Creative Commons Attribution License. 
ideologie is omvorm, deurdat vrouens in die rigting van huislik-verwante beroepe gestuur is. Dus is die tuisfront eenvoudig verbreed om met dié van die kolonie en die Britse Ryk saam te val. Organisasies is opgerig om die vroulike arbeidsmag in te span en nuwe projekte met dieselfde doelwit is van stapel gestuur.Die verandering wat dit teweeggebring het, het noodwendig gelei tot spanning op verskeie gebiede, aangesien dit die heersende stand van sake drasties beïnvloed het.

Sleutelwoorde: Wit vrouens; geslagtelikheid en die Britse Ryk; huislikheid; huishoudelikheid; Suid-Rhodesië; Tweede Wêreldoorlog

\section{Introduction}

Southern Rhodesia was occupied in 1890 and became independent in 1980 as Zimbabwe. It was established as a settler colony similar to French Algeria and British Kenya. For this and other reasons, the migration of white women to Southern Rhodesia and their domestic roles as mothers of the imperial race, among other things, was greatly valued. ${ }^{1}$ The early colonial environment was generally not considered ideal for white women and children, given the shortage of what were considered basic necessities and the prevalence of diseases. Thus, in the first two years of colonisation, white women were barred from the colony. The result was that the sex ratio in the colonies was acutely in favour of men, at least before the Second World War. ${ }^{2}$ When white women began to flock into the country in their numbers, they brought with them the domestic ideology of the Western world. This ideology prescribed women's place as the home. In colonies such as Southern Rhodesia, white women had their domestic drudgery relieved to a certain degree because of the presence of domestic servants. However, this must not be taken to imply that the domestic responsibilities had been totally lifted from their shoulders. In fact, women were expected to supervise and teach their domestic workers. In some instances too, white women continued with other domestic responsibilities such as cooking and darning clothes.

This article examines the experiences of urban white women in Southern Rhodesia during the Second World War and their contributions towards this war. It argues that the Second World War had far reaching effects on white women's roles and status in Southern Rhodesia. However, it was more a case of their domesticity

\footnotetext{
${ }^{1}$ For an assessment of white women's emigration to the British Empire see J. Bush, "'The Right Sort of Woman': Female Emigrators and Emigration to the British Empire, 1890-1910", Women's History Review, 3, 3, 1994. In non-settler colonies such as Nigeria, the settlement of white women was actually discouraged at least up to the Second World War. See H. Callaway, Gender, Culture and Empire: European Women in Colonial Nigeria (Macmillan, Basingstoke, 1987).

${ }^{2}$ John Pape notes that it was not until 1921 that white women population reached 40 per cent of the settler population. See J. Pape, "Black and White: The 'Perils of Sex' in Colonial Zimbabwe", Journal of Southern African Studies, 16, 4 1990, p 715. See also A.S. Mlambo, White Immigration into Rhodesia: From Occupation to Federation (Harare, University of Zimbabwe Publications, 2000).
} 
being reconfigured because their increased participation outside the home continued to mirror their domesticity. The paper also notes that the war bred a number of conflicts and tensions as the state attempted to maximise on women's labour power to either replace men or embrace the new opportunities being created by the wartime situation.

The article uses sources largely from the National Archives of Zimbabwe (NAZ) which include minutes of meetings; newspaper articles; diaries; biographies; personal letters; and newsletters; among other sources. As Antoinette Burton cautions us, the archive whether institutional or personal, should be subjected to "continuous suspicion and radical doubt." ${ }^{3}$ Fitzgerald points out that "Archives function to institutionalize historical memory and the public persona of the archive should neither be taken for granted nor readers seduced by its contents." ${ }^{4}$ The print media - in the form of national newspapers, newsletters and magazines produced on and by white women's organisations and individual women - helped among other things to give a broader view of public opinion and individual perceptions. ${ }^{5}$ It has also helped in the triangulation of evidence from the archival documents.

\section{White women in the colonies: A brief review of the literature}

The section looks briefly at studies of white women in the colonies, what some have termed gender and empire; it also examines works specifically on Southern Rhodesia's white women. Philippa Levine describes the subject of gender and empire as not only involving repopulating the colonial stage "with a more diverse cast of historical protagonists", but also an exploration of "social processes and power using sexual differences as a key but by no means unique analytic." 6 The initial works on gender and empire, however, sought to re-inscribe white women in the writing of colonial history by giving them visibility in imperial studies and thus simply replacing male with female protagonists. However, Haggis is critical of such writings, arguing that "presenting voices of white women in a singular authenticity reduces the historical narrative to series of parallel tracks essentially unrelated to each other."7

\footnotetext{
${ }^{3}$ A. Burton, "Thinking Beyond Boundaries: Empire, Feminism and the Boundaries and Domains of History", Social History, 26, 1, 2001, p 66. For other critical reviews on the use of archives in gender studies see C. McEwan, "Building a Postcolonial Archive; Gender, Collective Memory and Citizenship in Post-apartheid South Africa", Journal of Southern African Studies, 29, 3, 2003; and T. Shepard, "History is Past Politics? Archives, 'Tainted Evidence', and the Return of the State", The American Historical Review, 115, 2, April 2010, pp 474-483.

${ }^{4} \mathrm{~T}$. Fitzgerald, "Archives of Memory and Memories of Archive: CMS Women's Letters and Diaries 1823-35", History of Education: Journal of the History of Education Society, 34, 6, 2005, pp 657-674.

${ }^{5}$ Some of the women's organisations that produced newsletters/magazines were the Association of Women's Clubs; the Federation of African Women's Clubs; Business and Professional Women's Club; the National Housewives Register; Rhodesian Association of University Women; and the University of Rhodesia Women's Club.

${ }^{6}$ P. Levine, "Introduction: Why Gender and Empire?" in P. Levine (ed.), Gender and Empire (Oxford University Press, Oxford, 2004), p 1.

${ }^{7}$ J. Haggis, "White Women and Colonialism: Towards a Non-Recuperative History", in R. Lewis and S. Mills (eds), Feminist Postcolonial Theory: A Reader (Routledge, New York, 2003)
} 
Scholars such as C. Oliver were pioneers in the study of white women in the colonies (particularly outside India) and her study discusses their historical experiences as explorers, missionaries, and adventurers. ${ }^{8}$ Another pioneering work is one edited by Sheila Ardener and Helen Callan. ${ }^{9}$ This book explores the experiences of white women, particularly the wives of the colonialists. They argue that these women were incorporated, meaning that their roles and status were derived from the status of their husbands. ${ }^{10}$ This analysis is persuasive but must not be universalised. As Karen Hansen notes, the notion of incorporation helps to highlight the centrality of gender in colonial projects. ${ }^{11}$ However, it also universalises the experiences of wives in a colonial setting and it suggests a lack of independent action or functioning among white married women, and also assumes that these women were passive recipients of incorporation. Evidence in this paper demonstrates some degree of independence and flexibility of colonial wives in their roles in society. Although the dominant ideology suggests incorporation for married white women, many wives took up independent employment, embarked on volunteer work and some even became politically involved and in so doing, to a certain degree they defied being incorporated.

Another cutting-edge study on gender and empire is one by Helen Callaway, an anthropologist, on white women in colonial Nigeria. ${ }^{12}$ Callaway makes intensive use of interviews and her work demonstrates how men always had decision making status in Nigeria's colonial society. Looking at white women in the professions and colonial administration as well as the colonial state's attitudes and policies towards these women, Callaway demonstrates how patriarchy and gender stereotypes defined the experiences and positions of European women in Nigeria. Similarly, Karen Hansen's work on white women in post-World War II Northern Rhodesia examines the historical experiences of these women in wage employment, volunteer work and their domestication in the "private" sphere. ${ }^{13}$ While these works must be commended for challenging the androcentric nature of imperial histories, they have been criticised for being largely recuperative and excluding the metropole as part of the nexus of empire. Jane Haggis is sceptical about the recuperative approach which focuses on women alone at the expense of other players noting that this, among other things, "does little to capture the relations between women across the colonial divide". ${ }^{14}$

p 164. Also see J. Haggis, “Gendering Colonialism or Colonising Gender? Recent Women's Studies: Approaches to White Women and the History of British Colonialism", Women's Studies International Forum, 12, 1990, pp 105-112.

${ }^{8}$ C. Oliver, Western Women in Colonial Africa (Greenwood Press, London, 1982).

${ }_{9}^{9}$ S. Ardener and H. Callan (eds), The Incorporated Wife (Croom Helm, London, 1984).

${ }^{10}$ Ardener and Callan (eds), The Incorporated Wife, pp 1-2.

${ }^{11}$ K. Hansen, "White Women in a Changing World; Employment, Voluntary Work and Sex in Post-World War II Northern Rhodesia", in N. Chaudhuri and M. Strobel (eds), Western Women and Imperialism: Complicity and Resistance (Indiana University Press, Indianapolis, 1992), p 250.

12 Callaway, Gender, Culture and Empire.

${ }^{13}$ Hansen, "White Women in a Changing World".

${ }^{14}$ Haggis, "White Women and Colonialism", p 164. 
There has also been a growing number of edited works exploring various aspects of gender and empire, a few of which will be referred to. The 1984 pioneering work of Ardener and Callan has already been noted. Another pioneering piece is one from Nupur Chaudhuri and Margaret Strobel, published in 1992 that portrays white women in the colonies as either extending colonialism or sabotaging the empire. ${ }^{15}$ Such bifurcation of white women's experiences has also been criticised for oversimplifying their otherwise complex experiences. ${ }^{16}$ In their 1997 edited collection, Frederick Cooper and Ann Stoler note that colonial society was neither homogeneous nor without conflicts. Colonial society was wrought in tensions that took various forms including gender, race and class. ${ }^{17}$ Philippa Levine's edited work ${ }^{18}$ has expanded on this field, addressing "the history of British colonialism from gendered perspectives on both sides of the coloniser/colonised divide, and in between too."19 Besides providing a theoretical framework with a more global outlook, these works have also made it possible to compare and contrast gender and colonialism in different countries and continents.

Scholars have also recently taken interest in the themes of empire and sexuality which is also central to appreciating gender trends in the empire. Ronald Hyam's work is one of the path-breaking works in this direction, exploring sexuality in both the metropole and the colonies. ${ }^{20}$ However, as far as white women's experiences in the colonies are concerned, Hyam's book disappoints because the emphasis is largely on the sexuality of white men and that of the indigenous population. Indeed, the most discussed aspect of empire and sexuality is the experiences of indigenous women and on this the works by Luise White, Elizabeth Schmidt and Teresa Barnes, ${ }^{21}$ among others, have much to offer. These studies have contributed to our understanding of how the colonial environment shaped prostitution by indigenous women and how this prostitution also impacted on the colonial system. In many ways, they give agency to the indigenous women showing how they were fighting for survival in an otherwise restrictive and low-opportunity environment.

${ }^{15}$ Chaudhuri and Strobel (eds), Western Women and Imperialism. Strobel also partnered in editing a book that explores women's experiences beyond the boundaries of the Western world. See C. Johnson-Odim, and M. Strobel (eds), Expanding the Boundaries of Women's History: Essays on Women in the Third World (Indiana University Press, Indianapolis, 1992).

${ }^{16}$ See Haggis, "White Women and Colonialism".

${ }^{17}$ F. Cooper and A. Stoler (eds), Tensions of Empire and Colonial Cultures in a Bourgeois World (University of California Press, Berkeley and Los Angeles, 1997).

${ }^{18}$ Levine (ed.), Gender and Empire.

${ }^{19}$ M. Rutherdale, Review of P. Levine (ed.) Gender and Empire, in Gender and History, 19, 3, 2007, p 607.

${ }^{20}$ R. Hyam, Empire and Sexuality: The British Experience (Manchester University Press, Manchester, 1990).

${ }^{21}$ L. White, The Comforts of Home: Prostitution in Colonial Nairobi (University of Chicago Press, Chicago, 1990); E. Schmidt, Peasants, Traders, and Wives: Shona Women in the History of Zimbabwe, 1870-1939 (Heinemann Educational Books, London, 1992); T. Barnes, "We Women Worked so Hard": Gender, Urbanization, and Social Reproduction in Colonial Harare, Zimbabwe, 1930-56 (Heinemann, Portsmouth, 1999). 
Studies centred on white women have been largely absent or they simply made brief appearances in Zimbabwean historiography, even at a time when other histories such as those of African women or those that engaged with the gender aspects of colonialism began to take shape in the mid-1990s. ${ }^{22}$ This is probably because white women were part of the privileged classes and therefore were seen as willing accomplices in the oppression of the African population. Admittedly, there are some works that look at white women's sexuality but this is largely in relationship to African men. In separate studies, for example, Elizabeth Schmidt, Jock McCulloch and John Pape examine the alleged sex perils that took place in Southern Rhodesia and how, in part, these were instigated by the control of white women's sexual behaviour. ${ }^{23}$ In a more recent study, Oliver Phillips examines the report on prostitution compiled in 1915 by Brundell, the superintendent of the British South Africa Police (CID), and uses this to explore the fears of the purported threat of interracial sex in Southern Rhodesia. ${ }^{24}$ He makes similar conclusions to those reached by Pape and McCulloch regarding the impact (be they intended or unintended) of these anxieties. These scholars show how white women's sexual conduct was a concern of settler society and how the society sought to protect its women from the imagined black peril. ${ }^{25}$

However, in recent years works have emerged that attempt a sustained and rigorous analysis of white women in colonial Zimbabwe. In the post-colonial period, Deborah Kirkwood is arguably one of the first scholars to write academic works on white women in colonial Zimbabwe. ${ }^{26}$ One of her works seeks to analyse how the idea of a "suitable" wife was embedded in some educational institutions in Britain and Rhodesia. ${ }^{27}$ In another study she examines the experiences of white women as wives

\footnotetext{
${ }^{22}$ Some of the works that have been written on African women in colonial Zimbabwe include Schmidt, Peasants, Traders, and Wives; D. Jeater, Marriage, Pervasion, and Power: The Construction of Moral Discourse in Southern Rhodesia 1894-1930 (Clarendon Press, Oxford, 1993); and Barnes, "We Women Worked so Hard".

${ }^{23}$ E. Schmidt, "Race, Sex, and Domestic Labor: The Question of African Female Servants in Southern Rhodesia, 1900-1939", in K. Hansen (ed.), African Encounters with Domesticity (Rutgers University Press, New Jersey, 1992); J. McCulloch, Black Peril, White Virtue: Sexual Crime in Southern Rhodesia, 1902-1935 (Indiana University Press, Indianapolis, 2000); and Pape, "Black and White".

24 O. Phillips, "The Perils of Sex and the Panics of Race: the Dangers of Interracial Sex in Colonial Southern Rhodesia", in S. Tamale (ed.), African Sexualities: A Reader (Pambazuka Press, Cape Town, 2011).

${ }^{25}$ See Pape, "Black and White". Sex perils referred to perceived sexual threats that black women received from white men and white women from black men. The black peril, in particular, was the perceived sexual threat that black men posed on white women. Pape and some newspapers of the time interpreted the white peril to have meant the perceived sexual threat of white men to black women. However, in the Brundell Report, the term "white peril" was used to refer to white women whose "unruly" sexual behaviour caused a threat to the good image of white society and also caused the black peril by their unseemly behaviour.

${ }^{26}$ Ardener and Callan (eds), The Incorporated Wife.

${ }^{27}$ D. Kirkwood, "The Suitable Wife: Preparation for Marriage in London and Rhodesia/ Zimbabwe", in Ardener and Callan (eds) The Incorporated Wife.
} 
in various sectors of the Rhodesian society, arguing that these women were, for the most part, "incorporated wives". ${ }^{28}$

Much more recently, Kate Law has conducted sterling research on the experiences of white women in Southern Rhodesia. Her works go beyond the analysis given by Kirkwood offering wider and deeper discussions of white women's experiences. Law not only produces biographical works but has also made a cuttingedge analysis of the gender terrain of Southern Rhodesia's settler society between the 1950s and 1980s. Her analysis, among other things, exposes the contradictions and challenges present within this society, emanating in part from the gender ideologies. ${ }^{29}$

\section{White women and domesticity in Southern Rhodesia}

Domesticity is a historically constructed notion with several layers of meaning. ${ }^{30}$ The term is gender neutral but usually it is discussed, "with a strongly gendered interest and in conjunction with the life of women, either as an oppressive regime or as a potential resource towards liberation". ${ }^{31}$ The concept also conjures up images of a physical space, such as the home; the nature of work, such as home keeping; and the occupation, such as that of a household servant. ${ }^{32}$ In industrialised Western Europe, domesticity certainly ordered the roles and status of women.

The domestic ideology or domesticity has always found its greatest expression in the form of homemaking/housewifery (private domesticity) as a prescribed and "suitable" occupation for women. Housewives or homemakers were stay-at-home wives as opposed to those who engaged in formal employment or followed a career path. The formulation and entrenchment of the domestic ideology in Southern Rhodesia was the work of various forces in this country. The colonial state and society in many ways ordered the roles and status of white women in Southern Rhodesia. The former instituted policies and pieces of legislation that sustained domesticity for white women. To a great extent, women's organisations throughout the colonial period also played their role in encouraging domesticity, criticising

${ }^{28}$ D. Kirkwood, "Settler Wives in Southern Rhodesia: A Case Study", in Ardener and Callan (eds), The Incorporated Wife.

${ }^{29}$ See her following works: K. Law, "Writing White Women: Whiteness, Gender, Politics and Power in Rhodesia, c. 1950-1980", PhD thesis, University of Sheffield, 2012); “"Even a Labourer is Worthy of his Hire: How Much More a Wife?', Gender and the Contested Nature of Domesticity in Colonial Zimbabwe, c. 1945-1978", South African Historical Journal, 63, 3, 2011; "Making Marmalade and Imperial Mentalities: The Case of a Colonial Wife", African Research and Documentaries, 113, 2010; and "Liberal Women in Rhodesia: Report of the Mitchell Papers, University of Cape Town", History in Africa, 37, 2010.

${ }^{30}$ K. Hansen, "Introduction: Domesticity in Africa", in Hansen (ed.), African Encounters with Domesticity, $\mathrm{p} 3$.

${ }^{31} \mathrm{~L}$. Habib and T. Cornford, "Computers in the Home: Domestication and Gender", Information Technology and People, 15, 2, 2002, p 160.

32 Hansen, "Introduction", p 3. 
anything that tended to take a different course. They used the print media (magazines and newsletters) for propaganda on the virtues of domesticity.

The Rhodesian settler community, like several other British settler societies around the world, was greatly influence by the Victorian era in many of its societal values - including its gender terrain. Referring to Rhodesian women's lack of political participation in the 1960s Muriel Rosin, ${ }^{33}$ one of the only three women to become a member of parliament during the colonial era, blamed this on "a certain lingering of the Victorian attitude." 34 Kirkwood also notes that men and women in Rhodesia "accepted with little questioning the social rituals which derived from the metropolitan culture which they wished to reproduce". ${ }^{35}$ Thus cultural values were imported from England together with the material aspects of English life. However, the degree to which Victorian domesticity was reproduced in colonial societies in general and Southern Rhodesia in particular should not be overstressed. While Victorian domesticity may have influenced the British colonies, it is however, important to emphasise that the local colonial environment reproduced a peculiar form of domesticity despite feeding on Victorian culture. Ann Stoler echoes a similar observation, noting that

... colonial cultures were never direct translations of European society planted in the colonies, but unique cultural configurations, homespun creations in which European food, dress, housing, and morality were given new political meanings in the particular social order of colonial rule. ${ }^{36}$

Admittedly, despite the local reformulations of Victorian domesticity there were some values borrowed from the metropole that remained. For example, women's place and destiny in both Victorian and colonial society was perceived as the home. In Southern Rhodesia, the idea of home as the suitable place for a married woman was buttressed by women's organisations, the state as well as individual settler women. In her address to the 1938 Annual Congress, the chairperson of the Federation of the Women's Institutes of Southern Rhodesia (FWISR), Mrs Trotman, remarked:

The Women's Institute key word was "home and country" [sic]. Home and family must come before everything else. The greatest service a woman could give to mankind was housekeeping in the true sense of the word, including the care of

\footnotetext{
${ }^{33}$ For a detailed discussion of Muriel Rosin's urban political experience see U. Kufakurinani and E. Musiiwa, "The Unsung Heroine: Muriel Ena Rosin's Urban Political Experiences in Rhodesia, 1945-1980", Heritage of Zimbabwe, 30, 2012, pp 36-48.

34 "She's the Only Woman MP in the Federation", Edinburgh Evening News, 24 March 1961. See M.H. Medoff, "Determinants of Political Participation of Women", Public Choice, 48, 3, 1986, p 245, who identifies cultural, ideological and male conspiracy as some of the factors that militate against women's participation in politics.

${ }^{35}$ Kirkwood, "Settler Wives in Southern Rhodesia: a Case Study", p 149.

${ }^{36}$ A. Stoler, "Rethinking Colonial Categories: European Communities and the Boundaries of Rule", Comparative Studies in Society and History, 31, 1, 1989, p 136.
} 
children and their upbringing ... In fact, it is the fulfilment of our definite duties that is required of us in the world's civilisation. ${ }^{37}$

Such sentiments were also shared and buttressed in the Home and Country women's magazine produced by the FWISR. As noted, individuals subscribed to private domesticity for women. A Mrs Darlington's letter of complaint to the Rhodesian Herald in 1930 about the employment of married women confirms this observation. It read:

What does one get married for? I ask you, why, to keep a house, rear a family perhaps, to cook the meals, darn hubby's socks, etc. The married woman has a husband to keep her that's one reason why she gets married - to cease [formal] work. Who has the single girl to keep her?"38

She signed her letter: "I am etc. (Mrs) R. Darlington (married and unemployed as it should be.)" 39 Her belief, which mirrored Victorian domesticity, was that once married, a woman was duty bound to take up all domestic duties at home; employment was essentially the preserve of single women.

Similarly, society generally upheld housewifery as the ideal for married women. In fact being a housewife, at least before the Second World War, was also very much a status symbol. It was a social and economic statement and commented on the ability of the husband to fulfil his expected role as the provider for the family. In 1950, a letter to The Rhodesia Herald illustrates these social implications of housewifery in the early colonial period: "When I was a child it was considered a disgrace for a woman to abandon her home." 40 These notions buttressed the domestic ideology that pinned women to the private sphere. Admittedly, there were fewer occupations open to women before the 1950s but this does not dismiss the fact that the dominant ideology placed white women's proper place in the home as opposed to taking up a career.

In official circles, the stereotyping of married women as destined for housewifery also lingered on. This is notwithstanding the liberalisation of posts for married women in the 1930s. Thus,

... until 1971, a woman who married while occupying a permanent post in the civil service was required to resign or was discharged. If she wished to stay on, she had to accept a temporary position and the concomitant poorer leave, holiday and promotion benefits or profits. ${ }^{41}$

\footnotetext{
${ }^{37}$ FWISR, Home and Country, 1, 3, 1938, p 5. Emphasis added.

38 The Rhodesia Herald, 6 March 1930.

${ }^{39}$ The Rhodesia Herald, 6 March 1930.

40 The Rhodesia Herald, 5 September 1950.

${ }^{41}$ P. Godwin and I. Hancock, "Rhodesians Never Die": The Impact of War and Political Change on White Rhodesia c.1970-1980, Oxford University Press, Oxford, 1993, p 23.
} 
For the state, therefore, a married woman's place was the home and her commitment was first and foremost to her children and her husband. The temporary post she was offered after marriage would allow her to be flexible in terms of leaving work or having holidays to accommodate her husband's programmes. All this served to sustain and entrench the domestic ideology which relegated women's place to the private domain. As will be shown, the First and Second World Wars, however, had far reaching impacts on white women's domesticity because an increasing number of these married women moved out of the cocoons of the private sphere and replaced the men who went to the war front or simply took up the ever increasing jobs created by the war economy. ${ }^{42}$

\title{
White women and the Second World War: escaping the cocoons of domesticity?
}

In 1939 Europe went to war, ultimately drawing in countries in other parts of the world. This war, like the First World War of 1914-18, impacted on the roles that women played in their societies, albeit in a much more revolutionary and deeper way. The prevalent domestic ideology that ordered white women to stay at home as wives and mothers changed radically as a result of the world wars. When the men went to the warfront, women took the advantage of employment opportunities created by the war economies. During the two wars, white women increasingly left the confines of the home to replace men who had gone to the warfront. These men had occupied various jobs, largely in the public service, and women came in particularly in the clerical services. When compared to the First World War, the Second World War witnessed greater participation of white women outside the home as part of their contribution to the war effort. This was partly because of the intensity of participation of Southern Rhodesia, which was far greater during the Second World War. Even in Europe itself, similar trends were witnessed with regard to women's participation in the war economies. Bonnie Anderson and Judith Zinsser indicate that:

\begin{abstract}
far more than during World War I, women enabled industries to increase production and keep functioning. In Great Britain ... about twice as many women worked in war industries or the armed forces in World War II as did in World War I. 43
\end{abstract}

Southern Rhodesia, like most of the British colonies was expected to contribute towards the war effort in various ways, direct and indirect. Men were sent to the warfront; camps for prisoners of war were put in place; agricultural production was harnessed to serve the British market; financial and material resources were generated; and air training schemes established. White women in the colonies also contributed towards the war effort. Their participation constituted a reformulation of, rather than an assault on domesticity. This is because during the war, the

\footnotetext{
42 See U. Kufakurinani, "While a Career is Vital for a Man it is Optional for a Woman: White Women in the Southern Rhodesia Public Service, 1914-c. 1965", MA dissertation, Economic History Department, University of Zimbabwe.

${ }^{43}$ B.S. Anderson and J.P. Zinsser, A History of Their Own: Women in Europe from Prehistory to the Present, Volume. 11 (Penguin Books, London, 1988), p 309.
} 
boundaries of home had been conveniently shifted to coincide with those of the nation and women's war effort was encouraged in the name of defending "the home and the empire".

The participation of white women bred conflicts and tensions because disagreements erupted over a number of issues including government policy towards women's labour power. These tensions were in themselves "struggles within a struggle" and confirm Stoler and Cooper's thesis of tensions of empire which posits that colonial societies were neither homogeneous nor a smooth sail because they were wrought in tensions that took various forms including gender, race and class. ${ }^{44}$

As "mothers of the nation", white women participated in activities outside the home to defend the homeland. As noted, this participation was in essence an extension of the boundaries of home to coincide with those of the nation and the empire. Noteworthy is the fact that more often than not, women continued to embrace domesticity in this "enlarged home". Commenting on the impact of the two world wars on women's roles in Europe, Stevi Jackson makes a similar observation, noting that "the boundaries between the private haven of the home and the outside world were symbolically re-drawn so that the home became equated with nation." 45 Although this paper is concerned mainly with the impact of the Second World War, some comparative remarks must be made about the First World War. Indeed, both wars contributed to the increased employment of female labour outside the home in Southern Rhodesia.

Acknowledging the increased employment of women in the public service as a result of the First World War, in 1917 the Committee on Women Clerks and Typists maintained that "the employment of a certain number of ladies [was] due directly to the abnormal conditions caused by the war and the employment of others [was] indirectly due to the same cause". ${ }^{46}$ Prior to the war, clerical posts had been largely occupied by men. Once women started to be employed for clerical services, their economic value was quickly recognised because they were paid less than their male counterparts for the same work. In the light of this, the committee made the following recommendations:

In the opinion of the Committee the experience of recent years shows beyond doubt that a certain number of posts in the Civil Service can be filled by ladies not only more economically but more efficiently than by male clerks and that the

\footnotetext{
${ }^{44}$ Cooper and Stoler (eds), Tensions of Empire and Colonial Cultures.

45 S. Jackson, "Towards a Historical Sociology of Housework: A Materialist Feminist Analysis", Women's Studies Forum, 15, 2, 1992, p 160.

${ }^{46}$ National Archives of Zimbabwe (hereafter NAZ), A/3/7/23, Civil Service, Women Clerks and Typists, G. Ade Report, Submitted by the Committee on Lady Clerks and Typists, 11 April 1917.
} 
permanent retention in the Civil Service of a certain number of ladies is justified. ${ }^{47}$

In 1917, the recommendation of the Bagshawe Committee on Lady Clerks must be appreciated within the context of the economic value of lady clerks. The committee advised that "certain forms of the clerical work ... such as the record work of some offices could be carried out with greater efficiency and economy by suitable lady clerks". 48 This realisation of women's economic value was brought to the fore by the circumstances created by the First World War.

The Second World War had even greater far-reaching effects on the formal employment of women; the mobilisation of white women's labour became much more intense. As noted, part of the reason for this increased impact is to be seen in the fact that Southern Rhodesia had greater and more direct participation in this world war than it did in the first. For instance, the country hosted prisoners of war; war refugees; as well as some of the troops. ${ }^{49}$ Research suggests that more than any other historical event, the Second World War presented greater opportunities for women to take up employment outside the home - particularly in government service (see Table 1 below). The demand for women's labour was perhaps felt most in the defence services where a number of men left for the war front. Until the Second World War, both the military and the police services in Southern Rhodesia were predominantly male domains on the grounds that "the duties they performed were too strenuous and dangerous for the 'weaker sex"'. ${ }^{50}$ However, shortages of male personnel during the Second World War meant that white women increasingly joined the forces and their labour became highly valued.

In 1941, correspondence on white women's labour in the defence services summed up the desperate labour situation in these government departments, noting that the formation and expansion of industry and air services contributed to a large demand for women recruits between the age of 18 and 45.51 The national expansion of the administrative services (Air and Defence Headquarters), for example, meant a growing demand for women to fill different positions including those as civilian clerks. ${ }^{52}$ In this light, the correspondence noted, "it is clear therefore that the demand

${ }^{47}$ NAZ, A/3/7/23, Civil Service, Women Clerks and Typists, G. Ade Report, Submitted by the Committee on Lady Clerks and Typists, 11 April 1917.

${ }^{48} \mathrm{NAZ}, \mathrm{A} 3 / 7 / 23$, Lady Clerks in Civil Service, Increase in Salaries, Bagshawe Committee on Lady Clerks, 23 March 1917. Emphasis added.

${ }^{49}$ For fuller details on Polish refugees in Southern Rhodesia see T. Muguti, "An Economic and Social History of Polish Refugees in Zimbabwe during and after World War Two", MA dissertation, University of Zimbabwe, 2001.

${ }^{50}$ M. King, "Serving in Uniform: Women in Rhodesian Defence Forces and the Police, 19391980", BA Honours essay, History Department, University of Zimbabwe, 2000, p 7.

${ }^{51}$ NAZ, S726 W13/1/1-15/1/1, Women Power Policy 1940-1945, Correspondence on Women Power Policy from Defence House Headquarters, 17 November 1941.

52 NAZ, S726 W13/1/1-15/1/1, Women Power Policy 1940-1945, Correspondence on Women Power Policy from Defence House Headquarters, 17 November 1941. 
is real, urgent and unlikely to diminish". ${ }^{53}$ The situation did not seem hopeful because the correspondence on white women's labour observed that "all useful 'free female labour' has already been absorbed". ${ }^{54}$ At one time, the army contemplated recruiting white women clerks from those already employed in the civil service. However, this proposal was resisted because it was felt that it would only cause more confusion in government services as a whole, given the fact that the public service was experiencing severe labour shortages as a result of the war. It is for this reason that the Women's Auxiliary Territorial Service (WATS) was established in June 1940 as a desperate measure to alleviate the crisis by looking for white women to perform various duties including clerical services.

Table 1: Number of gainfully employed white women between 1926 and 1941

\begin{tabular}{|c|c|c|c|c|}
\hline Year & $\mathbf{1 9 2 6}$ & $\mathbf{1 9 3 1}$ & $\mathbf{1 9 3 6}$ & $\mathbf{1 9 4 1}$ \\
\hline $\begin{array}{c}\text { No. of } \\
\text { employed } \\
\text { white women }\end{array}$ & 2,738 & 3,197 & 4,675 & 6,913 \\
\hline $\begin{array}{c}\text { Gainfully } \\
\text { employed } \\
\text { women per } \\
1,000\end{array}$ & 157 & 176 & 186 & 246 \\
\hline
\end{tabular}

Source: Adapted from the Report on the Census of the Population of Southern Rhodesia, Part VII, Industries and Occupations of the European Population, 6 May 1941.

The Women's Auxiliary Territorial Service made a crucial contribution towards the war effort, including performing duties as drivers, post-women and mess assistants in training camps. Over time, WATS members were employed in other departments such as catering, stores, workshops and the manufacturing of ammunition at the Bulawayo factory. ${ }^{55}$ Its successor, the Southern Rhodesia Women's Auxiliary Military Service (SRWAMS) was established in 1941, and did not deviate much from the roles played by its predecessor except that the new association was, in the words of Monica King, "an improved organised unit". ${ }^{56}$ Members of SRWAMS underwent more intensive training and another notable feature was the requirement of a medical examination of women who wanted to be recruited into the service. The word "auxiliary" in both the WATS and the SRWAMS indicated the nature of the subsidiary role which they were expected to play. These organisations were not units of the military service; they were its appendages. This buttresses the observation that women's roles were largely a replay of their domesticity which was also hinged on

${ }^{53}$ NAZ, S726 W13/1/1-15/1/1, Women Power Policy 1940-1945, Correspondence on Women Power Policy from Defence House Headquarters, 17 November 1941.

${ }^{54}$ NAZ, S726 W13/1/1-15/1/1, Women Power Policy 1940-1945, Correspondence on Women Power Policy from Defence House Headquarters, 17 November 1941.

55 King, "Serving in Uniform", p 17.

56 King, "Serving in Uniform”, p 21. 
playing what was considered a subsidiary role at the home front, subsidiary to that of their husbands at the warfront. The term auxiliary also suggested that women's contributions were not central. As will be shown, this attitude adopted by the state attracted dissatisfaction and resentment from some women.

In an unprecedented fashion, several other white women's organisations in Southern Rhodesia brought their domesticity to the service of home and empire during the Second World War. Their contributions to the war effort also included raising resources for the soldiers (such as clothing); domestic responsibilities such as cooking and washing for the uniformed forces; as well as establishing child care facilities to help release more women towards the war effort. Women's organisations also actively participated in the welfare of refugees, internees and prisoners of war in the colony. During the Second World War, two white women's organisations, namely the Women's National Service League (WNSL) and the Federation of Women's Institutes of Southern Rhodesia (FWISR), stood out because of the nature and extent of their contributions.

When the WNSL was formed in 1939, it was in anticipation of a war crisis which would require the mobilisation of women's labour power to maintain stability in the workplace and the economy at large. One of its original objectives, which seems not to have yielded significant results, was to undertake a national registration exercise of the available labour from white women and their qualifications (to be discussed in detail below). The regulations of the organisation indicate that the government had "given official recognition to the WNSL as being Auxiliary to their Defence schemes". ${ }^{57}$

Just after the outbreak of the war, the secretary of the Department of Justice and Defence wrote to Lady Russell, the president of WNSL, requesting her to form "a unit on a voluntary basis to supply women for clerical duties to replace men at Defence Headquarters and other officers in the event of a national emergency". ${ }^{5}$ However, as will be shown, the WNSL did not play a crucial role in this respect. Instead, as the war progressed, WNSL assumed the role of securing material "comforts" such as blankets, pyjamas and shoes, among other things, for the military. Table 2 below documents just one year of the total comforts collected by WNLS. It seems these comforts were collected from 1940 to 1945 although records of only three years were accessed.

${ }^{57}$ NAZ, S750/W2/18, Women's National Service League 1939-1943, Regulations: Women's National Service League.

${ }^{58}$ NAZ, S750/W2/18, Correspondence from the secretary, Department of Justice and Defence to Lady Russell, 4 August 1939. 
Kufakurinani \& Nyambara - White women and WWII in Southern Rhodesia

Table 2: Total "comforts" received at the WNSL headquarters for the period 1 July 1941 to 30 June 1942

\begin{tabular}{|c|c|c|c|}
\hline General Items & Quantity & Hospital Items & Quantity \\
\hline Socks & 4,766 & Pyjamas & 797 \\
\hline Stockings & 1,570 & Hospital shirts & 100 \\
\hline Sea-boot stockings & 100 & Pneumonia jackets & 2 \\
\hline Kneecaps & 6 & Hospital stockings & 102 \\
\hline Hose tops & 1 & Bed socks & 10 \\
\hline Pullovers & 2,354 & Dressing gowns & 5 \\
\hline Seamen's jerseys & 191 & Surgeons' gowns & 5 \\
\hline Airmen's jerseys & 216 & Orderlies' gowns & 43 \\
\hline Searves & 3,370 & Overalls & 4 \\
\hline Helmets & 883 & Gauze masks & 48 \\
\hline Cap mufflers & 142 & Chest blankets & 29 \\
\hline Caps & 12 & Towels & 106 \\
\hline Cuffs & 53 & Face cloths & 4 \\
\hline Mittens & 297 & Hot water bottle covers & 158 \\
\hline Gloves & 66 & Bed pan covers & 30 \\
\hline Dressing gowns & 5 & Jug covers & 8 \\
\hline Holdalls & 1,157 & Pillow slips & 123 \\
\hline Hussifs & 1,939 & Eye-shields & 20 \\
\hline Glory bags & 629 & $\begin{array}{l}\text { Large number of } \\
\text { bandages and swabs }\end{array}$ & \\
\hline Ration bags & 1,542 & & \\
\hline Fly nets & 779 & TOTAL & 1656 \\
\hline Spine protectors & 120 & & \\
\hline Neck Protectors & 948 & & \\
\hline Cup Covers & 628 & & \\
\hline Handkerchiefs & 96 & & \\
\hline Cushions & 90 & & \\
\hline Total & 21953 & & \\
\hline
\end{tabular}

Source: Adapted from NAZ 482/456/39 Women's National Service League, 19391943, Women's National Service Bulletin, 1942.

WNSL's efforts in the supply of comforts for the military were acknowledged from as far away as the Middle East. The liaison officer from the office of the Rhodesian Military in the Middle East wrote:

without exception, both Rhodesian officers and women consulted affirm that these comforts have proved most valuable and welcome and substantiate my view that the only complaints are that these parcels of comfort have come too irregularly and in quantities too small to meet the demand. 59

${ }^{59}$ NAZ, S750/W2/18, Correspondence from the liaison officer, Office of the Rhodesia Military, Middle East, to Defence Head Quarters, Rhodesia, 11 February 1942. 
Comforts were also sent to "Rhodesian troops and other members of His Majesty's forces, including the Royal Navy at Simonstown and troops in France". 60 Clearly women's domesticity had been expanded beyond the home and the national frontiers to include empire. Perhaps it was because of the important role played by the WNSL that the organisation received direct support from the Rhodesian government. For example, in 1942, the WNSL's Bulletin reported that between July 1941 and June 1942, the National War Fund had "given the League Branches through its various Area Committees the sum of $£ 5,694$ for the purchase of wool and materials for making comforts". ${ }^{61}$

Further evidence of women's war effort going beyond the boundaries of Southern Rhodesia is seen when WNSL also assisted with the recruitment of women/girls to Kenya, where women's labour power was also in huge demand as a result of the Second World War. WNSL took responsibility for the screening of the women to prevent recruiting "an undesirable type ... who might give our colony a bad name". ${ }^{62}$ Thus WNSL also acted to safeguard the moral reputation of the colony. Lady Russell reported success for the majority who were recruited in Kenya. "The majority of our girls", she wrote, "are working happily. A few are disappointed because they are clerks and not drivers; others because they are not nearer the frontline." 63 Thus in their contribution to the war effort, women continued to be employed in what were considered feminine occupations.

The FWISR also played an active role in supporting the war effort. In the first instance, it allowed the WNSL to use its branch offices in the country for its activities. The FWISR also made financial contributions to the National War Fund through domestic oriented activities such as the selling of tea, flowers and other products associated with the home. ${ }^{64}$ It was this fund that was also used by the state to assist organisations such as the WNSL that were making contributions towards the war effort. Another activity conducted by the FWISR was the collection of Stramonium (Datura stramonium), a plant that has medicinal properties. In 1943, the chairperson of the FWISR reported:

This will be the last month of the collection of Stramonium. It is sad to think of the amount spoilt through the difficulty of drying it. The Selukwe Institute arranged for a drying room for the town members - a practical idea. Mazoe

\footnotetext{
${ }^{60}$ NAZ, S750/W2/18, Correspondence from the prime minister, Southern Rhodesia to the minister of External Affairs, Cape Town, 16 March 1940.

${ }^{61}$ NAZ, S750/W2/18, Correspondence from the prime minister, Southern Rhodesia to the minister of External Affairs, Cape Town, 16 March 1940.

${ }^{62}$ NAZ 482/456/39, Correspondence from Lady Russell, the vice-president of the WNSL to the prime minister, Mr Huggins, 2 October 1940.

${ }^{63} \mathrm{NAZ}, 482 / 456 / 39$, W. Russell (Women's National Service League) to Mr Beadle, parliamentary secretary to the prime minister, 23 January 1941.

${ }^{64}$ K. McClintock, "Women's Institutes Notes: Chairman's Comments on Many Matters of Great Interest", Vuka, 3, 5, 1943, p 37.
} 
Central has sent $3761 \mathrm{lbs}$. (dried) and offered natives in the reserve $2 \mathrm{~d}$. per lb. dried, or 9d. for $20 \mathrm{lbs}$ of undried Stramonium. ${ }^{65}$

Stramonium was eventually shipped to the metropole were it was valued for its medicinal properties that came in handy for the fighting soldiers. Women's organisations also extended their domestic duties to the military arena by providing catering and cooking services for military camps. In one of its meetings in 1941 the FWISR, for instance, encouraged its members to turn their attention to providing catering and cooking in military camps because it considered this type of service to be a "women's sphere and [one] where we could give great help". 66

FWISR branches also played a very important role in overseeing the welfare of Polish refugees ${ }^{67}$ and prisoners of war. ${ }^{68}$ This involved providing shelter, food, comforts and other necessities. A summary compiled in 1943 by Kathleen McClintock, at the time the chairperson of the FWISR, on the activities of this organisation during the war noted the following:

Social Services: (Convener, Mrs J. P. Mackenzie) - Has taken an active part in agitation for increased hospital accommodation, and dealt with questions concerning control of prices, the grading of meat, better conditions of VAD's ... convalescent homes for service and civilian invalids, priority ratings for essential goods, eviction of natives from the model village at Marandellas, installation of Polish women in village from which natives had been evicted, and the care of children whose mothers are in full-time employment. ${ }^{69}$

These activities demonstrate the important role played by white women and their contributions to the war effort. They also confirm the influence of the domestic ideology because women were channelling their energies outside the home. As Margaret Allen observes of British women during the Second World War, in Southern Rhodesia, “... some of the most central elements of the domestic ideal were attacked during the war, as women were encouraged to cut down on the time they spent on housework". ${ }^{70}$ Husbands and children could now be sacrificed in the name of the war as white women embraced the new emphasis on their identity as "mothers of the empire."

\footnotetext{
${ }^{65}$ McClintock, “Women's Institutes Notes: Chairman's Comments on Many Matters of Great Interest", Vuka, 3, 5, 1943, p 37.

66 NAZ S2791, Federation of Women's Institutes of Southern Rhodesia.

${ }^{67}$ K. McClintock, "Women's Institutes Notes: Preparing for the Gwelo Congress and Other Matters", Vuka, 3, 3, 1943, p 33.

${ }^{68} \mathrm{~K}$. McClintock, "Women's Institutes Notes: Summary of Year's Work by Officers and Conveners", Vuka, 1, 2, 1943, p 43.

${ }^{69}$ McClintock, “Women's Institutes Notes: Summary of Year's Work by Officers and Conveners", Vuka, 1, 2, 1943, p 43.

${ }^{70}$ M. Allen, "The Domestic Ideal and the Mobilisation of Woman Power in World War II", Women's Studies International Forum, 6, 4, 1983, p 403.
} 
However, it is also important to acknowledge other factors that pushed white women into employment apart from the pull factors associated with the increased demand. Women's increased employment outside the home was also a product of push factors such as the death of spouses (at times as a result of the war) as well as the rising cost of living during and after the Second World War. Tatenda Ganyaupfu notes that "by 1940, the cost of living in Southern Rhodesia increased slightly marked by a $3 \%$ rise in the cost of food, fuel, rent and lighting and a $23 \%$ advance in retail prices". ${ }^{71}$ Admittedly, as Ganyaupfu notes, the rise of the cost of living in Southern Rhodesia was modest in comparison with South Africa and UK. ${ }^{72}$ The continued rise in the cost of living beyond the war partly explains why the employment of women was neither drastically reduced nor reverted to the pre-war era. One working Rhodesian woman expressed this point in The Rhodesia Herald in 1950:

I go to work Sundays, holidays, and every day as a hotel receptionist - because I have got to, just to make ends meet ... my husband and I do not drink intoxicants; do not keep any Native Servants, and seldom go to the pictures. And yet it will take us all our time to pay for the licence of our little car. ${ }^{73}$

Another white woman made a similar remark in The Rhodesian Herald of the same year:

I am a home lover and would far rather stay at home, but I want to give my children opportunities which I could not have when a child, but my husband's salary is not sufficient with today's high cost of living, to live a normal life (we do not go to dances, sun-downer parties, etc.) and so I go to work. But still I have not money to burn. If I give up my job, my children would have to give up their dancing, horse riding etc. and would have to give up their thoughts of a career, one of which is to become a veterinary surgeon. ${ }^{74}$

Thus it appears that many white women were forced women to remain in the workplace and contribute to the welfare of the family because the husband's salary alone was being eroded by the ever increasing cost of living.

\section{Child care during the war: accommodating women's changing roles and status}

Child care was one of the biggest challenges to women's entrance into the labour market. Though most white households had domestic servants, ${ }^{75}$ there seemed to be some distrust in leaving children under the care of Africans for various reasons.

71 T. Ganyaupfu, "Economic Stabilisation through Government Regulation: A Review of Price Controls in Southern Rhodesia, 1939-1952", Honours essay, Economic History Department, University of Zimbabwe, 2013, p 30.

72 Ganyaupfu, “Economic Stabilisation through Government Regulation”, p 30.

73 The Rhodesia Herald, 16 September 1950.

74 The Rhodesia Herald, 11 September 1950.

75 Pape notes that "Even as early as 1904, there were 6,991 African domestic workers, more than one for every two white people in the colony", and adds that this ratio remained relatively constant until 1940. See Pape, "Black and White", p 701. 
Brundell's report referred to a case of assault allegedly committed by two African domestic servants on a 6 year old white girl. Part of the report read:

The attempt at rape by these natives resulted in the child contracting a venereal disease ... I make special reference to this case as it is one of the many offences of a similar nature although less serious. It constitutes a practical illustration of the danger attending the employment of male servants with the care and custody of children of tender age. ${ }^{76}$

A letter of advice to European women in the colonies by the East Africa Women's League reprinted in 1938 in Rhodesia, Home and Country, for white women in Rhodesia, also reflects on the fears that white women had about dependence on African domestic service:

During the past years there have been a number of cases of rape by natives on European women and children of varying age, and there have been cases of venereal diseases among little white girls which have been and are being proved to be the result of contact with native servants ... Facts such as these are proof that European children should never be given into the unrestricted care of native servants, and that the greatest watchfulness must be exercised by parents who should never allow their children of either sex to be with native servants, out of sight or earshot of a reliable European. ${ }^{77}$

This may well be an exaggerated picture where Rhodesian society was concerned. However, it indicates some of the fears, uncertainties and suspicions that white women held about their African domestic servants. It also partly explains why the issue of care for children was crucial if women's labour power was to be exploited fully.

The expansion of day care facilities for children in the form of crèches, for example, was one effort towards addressing the problem of care for white children. In my research, the first references to crèches for children of working mothers were made as early as 1936 and these crèches were run privately. In the same year, the FWISR impressed upon the government that it should "introduce Nursery Schools in the general educational scheme". ${ }^{78}$ This would see the establishment of public crèches which would be relatively cheaper because of government subsidies. At that point, the need for crèches was rationalised on the grounds that there was "a great desirability of providing occupations and pre-school training for the younger children

\footnotetext{
${ }^{76}$ NAZ, S1222/2, Black and White Peril in Southern Rhodesia: Special File, 1916, Report by Jos A. Brundell, the superintendent of the CID, BSAC Police, 13 March 1915. The report looked at prostitution by white women in Southern Rhodesia. It also made reference to some cases where African servants were alleged to have abused white children.

77 "Advice to European Women" (Reprinted with acknowledgement to East Africa Women's League), Rhodesia, Home and Country, 1, 3, 1938, p 43.

78 NAZ, S824/198/1, Correspondence from the Federation of Women's Institutes: Miscellaneous Subjects, 1943-1950, from the office of the inspector of schools to the director of Education, 10 July 1936.
} 
and eliminating or reducing the native nurse influence". ${ }^{79}$ In response to this request, the inspector of education, who usually attended the annual FWISR conferences, indicated that the time was not yet ripe for government's direct intervention with nursery schools because of the demand which, for him, was uncertain. ${ }^{80}$ However, he recommended that "government assistance be given towards the provision of Kindergarten material for the crèches which could be regarded as an experiment towards this direction". 81

During the Second World War, the demand for crèches became more urgent as women increasingly took up formal employment and needed child care services to enable their entry into the labour market. In 1941, the FWISR again made a plea to the government to establish nursery schools in various centres. ${ }^{82}$ This time, the government indicated that it did not have the capacity: "Buildings are not available and there is considerable difficulty in securing sufficient staff to deal with even those children within the normal school range."83

In 1942, a report issued by the FWISR Education Standing Committee claimed that "One crèche - 'Greenwood' - has been started at Salisbury and one at Bulawayo 'The Children's Home' - but owing to war conditions when so many women are employed in war work, we consider that more such establishments are urgently needed". ${ }^{84}$ The committee once again impressed upon the government that the issue of establishing crèches was now a "grave necessity". ${ }^{85}$ However, the government did succumb to pressure for more direct assistance in this regard. It proceeded to fulfil the promise of 1941 made by the inspector of education that:

the government would be sympathetic towards giving assistance to those who had made an effort of this kind [establishing crèches], but stressed that we [the government] could not subsidise small private schools whose teachers were not properly qualified for nursery school. ${ }^{86}$

The FWISR recorded the establishment of the first permanent government sponsored crèche in 1944 in Salisbury which would "fill a real need for many mothers" and declared that preference would be "given to children of mothers who

79 NAZ, S824/198/1, Correspondence from the Federation of Women's Institutes: Miscellaneous Subjects, 1943-1950, from the office of the inspector of schools to the director of Education, 10 July 1936.

${ }^{80} \mathrm{NAZ}, \mathrm{S} 824 / 198 / 1$, Correspondence from the office of the inspector of schools to the director of Education , 2 June 1936.

${ }^{81}$ NAZ, S824/198/1, Correspondence from the office of the inspector of schools to the director of Education , 2 June 1936.

82 NAZ, S824/198/1, Official note on the Conference of Women's Institutes, 1 October 1941.

${ }^{83} \mathrm{NAZ}$, S824/198/1, Official note on the Conference of Women's Institutes, 1 October 1941.

${ }^{84}$ NAZ, S824/198/2, Federation of Women's Institutes: Education Matters, 1943-1950, Report of the Standing Committee for Education of the FWISR, 1942.

85 NAZ, S824/198/2, Federation of Women's Institutes: Education Matters, 1943-1950, Report of the Standing Committee for Education of the FWISR, 1942.

${ }^{86}$ NAZ, S824/198/1, Official note on the Conference of Women's Institutes, 1 October 1941. 
[were] working all day". ${ }^{87}$ In 1946, A. Cowling, the director of education reported that the government had "decided as a policy to provide nursery schools in urban areas", 88 suggesting that the crèches would spread beyond Salisbury. The direct involvement of the state in the provision of children's day care service was by and large a product of successful lobbying by women's organisations and it helped to accommodate the transition taking place in women's domesticity.

When the FWISR originally advocated expansion and state involvement with the crèches during the war, this did not necessarily imply its support for working mothers or a change of attitude with regard to the primary role of women in society. Indeed, women's organisations such as the League for Professional and Business Women continued to stress the importance of women's private domesticity even during the war, arguing that the care of children was "the first duty and a satisfactory form of war service". ${ }^{89}$ However, during the war working women were also increasingly tolerated if not accepted by the Rhodesian state and society because they were considered to be serving a higher kind of domesticity. It is within this context that the campaigns for day care for children must be appreciated. However, it was hoped that the need for crèches would be limited to the war period. In its contribution to Vuka, in October 1944, the FWISR echoed these sentiments:

After the war, when it is hoped that the number of these mothers will be few, the aim of the crèche is to cater for those mothers who want to be relieved of the responsibility of their children for a few hours. Such a purpose is ideal, but it is hoped that the existence of the crèche will not encourage mothers to get jobs when [it is] ... not required that they do so. ${ }^{90}$

The FWISR still believed strongly in the traditional family setting where the husband worked while the wife was at home and it lamented "the gradual breaking down of the old conception of family life which ... ha[d] been greatly accelerated by war conditions". ${ }^{91}$ That same year, FWISR's convener for social services, Mary Mackenzie, in her contribution to Vuka, discouraged women's continued employment after the war. She noted:

\footnotetext{
87 "WI. Notes: Social Services versus the Federation", Vuka, 2, 2, October 1944, p 67. The full name of the journal was The Official Journal of the Rhodesia National Farmers' Union and the Rhodesia Tobacco Association. It was a monthly journal largely for farmers but the FWISR was also given space to publicise its activities and keep its members updated with Women's Institutes activities. The chairperson made a statement update in every issue and other notable members could also make contributions in this space.

${ }^{88}$ NAZ, S824/198/2, Correspondence from the secretary, A Cowling, Department of Internal Affairs to the secretary, FWISR, 22 January 1946.

${ }^{89}$ Quoted in King, "Serving in Uniform", p 15.

90 "WI. Notes: Social Services versus the Federation", Vuka, 2, 2, October 1944, p 67.

91 "WI. Notes: Social Services versus the Federation", Vuka, 2, 2, October 1944, p 67.
} 
A mother who is with her children all the time can seldom give them her best, but a mother who is only with her children at bed time is evading one of her greatest responsibilities in life - the day to day shaping of the child's character. ${ }^{92}$

The perceived increased delinquency of white children in government schools during the Second World War was attributed to the increasing absence of women from the home while making their contributions to the war effort. This argument was built on the philosophy that women were responsible for shaping children's characters but the war had not accorded them this opportunity because these women were now spending more time outside the home. The FWISR's Standing Committees for Education reported in March 1944:

Since the congress sat in 1943 we have investigated with the Government Official Resolution no. 7 regarding more consideration being given in government schools to the [shaping of pupils' characters] ... being cognisant of the lack of strictly moral behaviour on the part of the pupils. [He] informed us that teachers are doing what they can to rectify this state of things. The authorities attribute the increase in lack of strict moral behaviour to the fact that so many mothers are employed in War work, making home influence and supervision for the proper direction of the children's sense of morality difficult. ${ }^{93}$

After the war concern for the moral welfare of children continued to be presented as one of the many reasons why mothers should return to care giving at home after the war. However, economic dictates outweighed the fears of the perceived potential harm to the morality of their children as a result of the mother's employment outside the home. The following section examines some of the tensions and conflicts that arose as a result of the war.

\section{Wars within a war: tensions and conflicts}

The Second World War was not without its complications on the domestic front. A number of conflicts emerged on the roles that women were playing. This section discusses tensions and conflicts that women's labour triggered and accentuated in the home during wartime. Some of these conflicts arose when the government attempted to pool women's labour to replace men who had left for the war front. In certain cases conflicts arose over the role and status women assumed at this time. In other instances, women themselves began to press for greater recognition, having realised their value to the government.

In a desperate bid to harness female labour in the public service to replace men on active service, the colonial state embarked on a number of recruitment schemes. Two of these will be discussed as case studies because of the controversies and conflicts they aroused. The first was a scheme for the registration of all white

92 "WI. Notes: Social Services versus the Federation", Vuka, 2, 2, October 1944, p 67.

${ }^{93}$ NAZ, S824/198/2, Federation of Women's Institutes: Education Matters, 1943-1950, Standing Committees for Education, FWISR, 22 March 1944. 
women promulgated by an Act of Parliament in 1939. The second initiative was the introduction of a refresher course which involved the (re-) training of women clerks who had resigned. These women were to be trained in private schools at the expense of the government and were expected to replace men who had gone to the warfront. The state announced this scheme in 1940. Both these initiatives demonstrated an increase in the significance of female labour to the colonial government.

The 1939 National Registration Act introduced compulsory registration of white women in the colony between the ages of sixteen and fifty-five. White women who were sixteen years of age and older who came into the country had to register within seven days of their arrival or within ten days after reaching the age of sixteen. Employers were also expected to supply a register with statistics of the white women employees. ${ }^{94}$ As noted earlier, the WNSL was supposed to oversee this registration which was expected to help the state analyse its existing human resources (potential and actual) in anticipation of wartime labour demands. It was also about controlling this potential labour pool. (This was not the last time that the colonial regime attempted to put women under some kind of enforced control or surveillance. In the 1970s, during the liberation war, African women were subjected to a similar experience, albeit more intense, when they were obliged by law to be registered and obtain identity cards as part of the government's effort to control their mobility.)

Judging from some of the correspondence that ensued, the registration exercise of 1939 does not seem to have yielded spectacular results because there was a great deal of confusion over the implementation and adoption of the initiative. In 1940 , for example, one observer from the air force cast doubt on the success of the efforts of the WNSL in overseeing the registration exercise. A letter from the Rhodesian Air Group Headquarters read: “The Women's National Service League as a medium for the registration of women has been a dismal failure, whatever, they may say to the contrary." 95 This was also a reflection of a long standing wrangle between head of the Air Group Headquarters and WNLS in which the latter trivialised the role played by WNLS in general. The failure to achieve notable successes in the registration initiative can also be attributed to complications and delays in implementation. King notes that it was only in 1942 that actual registration began and even then, it was sluggish - and yet the need for white women's labour continued to rise. ${ }^{96}$ Eventually the WNSL shifted its attention from the registration exercise to the supply of material comforts for the troops, where, as already noted, it registered far greater success.

Perhaps the greatest achievement of the WNSL was its initiative to recruit women to serve in Kenya, as discussed above. However, this brought the organisation into direct conflict with the colonial government which was battling to meet its own

\footnotetext{
${ }^{94}$ M. King, "Serving in Uniform" p 14.

${ }^{95} \mathrm{NAZ}, 482 / 456 / 39$, Correspondence from the Rhodesian Air Training Group headquarters to the prime minister, G.M. Huggins, 2 October 1940. Emphasis added.

96 M. King, "Serving in Uniform", p 15.
} 
labour demands. Evidence suggests that Kenya was a popular destination for single white women from Southern Rhodesia because it seemed to hold better prospects compared to life in Southern Rhodesia. Women tended to resign from the public service to take up opportunities in Kenya. WNSL tried to protect themselves from the wrath of the government by accepting only those women who had been granted permission to resign by their supervisors. However, it is doubtful that this measure effectively cushioned the Rhodesian government from losses to their Kenyan counterparts. In any case, the very fact that WNSL was recruiting from Southern Rhodesia for a destination believed to have better prospects meant greater competition on the labour market for the Southern Rhodesian government.

Another source of conflict was the government's attitude towards WNSL and the role it played. The WNSL accused the government for taking WNSL for granted by not treating it in the same way that similar organisations were being treated in the empire. For example, the WNSL argued that elsewhere an organisation such as theirs would have been part of the army with a uniform and official recognition in the form of ranks. The members of the WNSL continuously requested the government to improve the status of the WNSL by treating it as if it were a military organisation. But these requests for improved status fell on deaf ears. A letter from the Rhodesia Air Training Group Headquarters advised the colonial government:

If there should be any wish that it [WNSL] should be reconstituted and divided into sections or units, put into uniform, ranks given to the officers, etc., they might be allowed to follow their fickle fancy, but for heaven's sake leave it as it is, a purely voluntary organisation in which the government shows a benevolent interest, but which it does not wish to interfere with. ${ }^{97}$

It is this "distant" interest of some government officials towards the WNSL that partly explains one complaint raised by Made Holdengarde, a member of the WNSL Bulawayo branch. She was complaining about the women having to operate without their own office and adequate office equipment and yet the organisation was playing a vital role during the war. She protested vehemently:

Candidly, I feel it is a gross injustice for the government to ask for the women of the country to do this work [voluntary activities] and yet to withhold the essential [recognition] and expect them [the women] to find the ways and means with which to run an office efficiently. ${ }^{98}$

The second measure, the refresher course scheme, was introduced in Salisbury and Bulawayo. These refresher courses were largely focused on shorthand, bookkeeping and typewriting. Married women with previous office experience were targeted to take up these courses so that "they would be fit to fill senior positions

\footnotetext{
${ }^{97}$ NAZ, 482/456/39, Correspondence from the Rhodesian Air Training Group headquarters, to the prime minister, G.M. Huggins, 2 October 1940.

${ }^{98} \mathrm{NAZ}, 482 / 456 / 39$, Letter from Made Holdengarde to the chairperson of the WNSL, 14 September 1939.
} 
vacated by men called away for military service". ${ }^{99}$ The colonial government took responsibility for the retraining of these women by providing subsidies to the selected schools. In Salisbury, the scheme did not arouse much controversy because there was only one private school which was automatically nominated to participate in the scheme. In Bulawayo, the nomination of one school to participate in the scheme out of the three existing private commercial schools generated discontent and scathing criticism from the two schools that were excluded. ${ }^{100}$ The commercial schools in Bulawayo were Williams Business Academy; Bulawayo School of Shorthand; and Kivell School of Bulawayo. The latter was the one nominated to take up the government scheme.

The two schools that were not selected felt that if indeed the goal of the state was to pool as much in the way of human resources as possible for the war effort, then every school had to participate. The principal of Williams Academy writing to T.W.W. Beadle, a local member of parliament, noted: "The singular action of the local Education Officer in this connection appears to violate all Government promises to ensure the pooling of all Rhodesian resources economically and otherwise." 101 The principals of the excluded schools were also bitter about the fact that Kivell, a school that had only been recently established, was given preference to undertake the initiative. For the principal of Williams Academy, this preference of a less experienced school, held them up "to ridicule in this and other places as being unfit to rank with a comparative newcomer into our particular ranks". 102

It seemed to all boil down to the public image that was being portrayed by the government's selection of a single school out of the three. Typical of private profitmaking institutions, the appointment of Kivell School and the message it was likely to send about the excluded schools was thus seen as potentially affecting their ability to make profitable business. The principal of Williams Academy's letter read as follows:

Again by this questionable appointment of the Kivell School as the sole operator to handle Government refresher courses in commercial education, Government is acting as an advertising adjunct to that school, and is definitely interfering with

\footnotetext{
${ }^{99} \mathrm{NAZ}, \mathrm{S} 482 / 198 / 40$, Government scheme for commercial training of women to replace men in 1940, correspondence to Kivell School re commercial tuition, from the Education Officer H.D. Sutherns, 18 February 1941.

100 The other private schools felt that the chosen school now had an unfair advantage over others because it was subsidised by the government in its operations. The fees at the chosen school were now more competitive than those at the other two schools.

${ }^{101} \mathrm{NAZ}, \mathrm{S} 482 / 198 / 40$, Government Scheme for commercial training of women to replace men 1940, Letter from Williams Academy School to Capt. T.W.W. Beadle, member of parliament, 13 July 1940.

102 NAZ, S482/198/40, Government Scheme for commercial training of women to replace men 1940, Letter from Williams Academy School to Capt. T.W.W. Beadle, member of parliament, 13 July 1940.
} 
the ordinary income of the other and much older and proven Commercial seminaries. ${ }^{103}$

In response to these criticisms, the government was only too glad to extend the scheme to the other two private schools. As in the previous arrangements with the schools that had been nominated initially, the policy was "not to accept beginners for free tuition as they [would by implication] require a longer period of instruction before being fit for employment". ${ }^{104}$

As the war ravaged on and labour demands persisted in the public service, the government broke its own stipulations by extending the administrative skills scheme to beginners in 1941.This new move was cause for another conflict with the private schools. The principal of Kivell School complained that the extension of government sponsored training to beginners would mean that the schools would incur losses because they did not enjoy substantial profits from the existing government sponsored refresher schemes. ${ }^{105}$ With overhead expenses rising on account of war conditions, one can appreciate the financial concerns that these schools raised against extending the government scheme to beginners. "We are all in agreement that we must protest as strongly as is possible against the new scheme",106 wrote N.S. MacLean, the principal of the Bulawayo School of Shorthand. For A.J. Williams of the Williams Business Academy, the working of such a scheme would "result in placing others and myself in a most humiliating and helpless position". ${ }^{107}$ The new scheme was no doubt very unpopular with the private commercial schools and it increased tension between the affected private schools and the government.

The Bulawayo School of Shorthand felt that the justification for the extension of the government scheme to beginners was fallacious, arguing that the said warinduced labour shortages were delusional:

The sole reason for the intended further encroachment by the Government on private enterprise is the alleged shortage of clerical workers ... I disagree entirely with this statement both from my own experience and also from information given by the Government Officer who authorizes me to refer to you for him. ${ }^{108}$

103 NAZ, S482/198/40, Government Scheme for commercial training of women to replace men 1940, Letter from Williams Academy School to Capt. T.W.W. Beadle, member of parliament, 13 July 1940.

104 NAZ, S482/198/40, Government Scheme for commercial training of women to replace men 1940, Letter from Ministry of Education to Williams Academy, 23 July 1940.

105 NAZ, S482/198/40, Letter from Kivell's School principal to the Education Officer, 18 February 1941.

106 NAZ, S482/198/40, Letter from the Bulawayo School of Shorthand to the Education Officer, 18 February 1941.

107 NAZ, S482/198/40, Letter from Williams Business Academy to the Education Officer, H.D. Sutherns, 19 February 1941.

108 NAZ, S482/198/40, Letter from the Bulawayo School of Shorthand to the Education Officer, 18 February 1941. 
Evidence forwarded by the principal of Kivell's Commercial School seems to buttress this point. He noted that in 1941, there were six married women clerks "trained, experienced and valuable in every way" that were unemployed. ${ }^{109}$ The principal went on to explain that in his opinion the solution did not lie in extending the government scheme to beginners but rather in "judicious advertising ... on the part of the Government Bureau". ${ }^{110}$ This, however, does not dismiss the fact that women's labour was in huge demand for, as the principal himself noted: the demand was so great that "young girls [were] being absorbed into commercial life without any training whatsoever". ${ }^{111}$ The continued protests against extending the scheme to the beginners ultimately won the day because the government suspended its plans in this respect.

Tension also arose between the government and white women employed by the Defence Service and these tensions were largely over salaries. The Women's Grading Board observed that the lower rates of pay and the "less lenient hours of work", as compared to those obtained in commerce, were largely responsible for the discontent of white women who were now turning to the private sector. ${ }^{112}$ The board then reviewed the salaries for women and recommended increases in the rates of pay, especially for the senior grades. ${ }^{113}$ However, this recommendation was turned down by the Treasury which was of the opinion that the existing rates of pay were high enough and that "it was not to be the policy of Government to compete with commerce". 114 The Treasury also felt that pay increases were unjustified because the rate of pay and conditions of service for white women employed in the Defence Service departments were already better than those in the public service and that any further concessions would only aggravate the situation. As a measure to retain women labour, especially for the office clerical jobs, the Treasury offered an alternative - all applications to resign were to be refused unless supported on bona fide medical or compassionate grounds. ${ }^{115}$ This did not resolve the conflict over remuneration and women no doubt continued to feel short-changed by the restrictive stipulations.

${ }^{109}$ NAZ, S482/198/40, Government Scheme for Commercial Training of Women to replace men, 1940, Letter from Kivell's School principal to the Education Officer, 18 February 1941.

110 NAZ, S482/198/40, Government Scheme for Commercial Training of Women to replace men, 1940, Letter from Kivell's School principal to the Education Officer, 18 February 1941.

111 NAZ, S482/198/40, Government Scheme for Commercial Training of Women to replace men, 1940, Letter from Kivell's School principal to the Education Officer, 18 February 1941.

112 NAZ, S726 W13/1/1-15/1/1, Women's Power Policy, 1940-1945, Women Civil Employees; Defence Departments, Draft Report by the Women's Grading Board, 23 March 1944.

113 NAZ, S726 W13/1/1-15/1/1, Women's Power Policy, 1940-1945, Women Civil Employees; Defence Departments, Draft Report by the Women's Grading Board, 23 March 1944.

114 NAZ, S726 W13/1/1-15/1/1, Women's Power Policy, 1940-1945, Women Civil Employees; Defence Departments, Draft Report by the Women's Grading Board, 23 March 1944.

115 NAZ, S726 W13/1/1-15/1/1, Women's Power Policy, 1940-1945, Women Civil Employees; Defence Departments, Draft Report by the Women's Grading Board, 23 March 1944. 


\section{Conclusion}

This article re-inserts the experiences of white women into the Zimbabwean historical narrative, challenging colonial, nationalist and patriotic historiographies that have tended to be androcentric and trivialise the contributions of white women to colonial society. In many ways, the study is a contribution to the small but growing number of studies dealing with the experiences of white women in the colonies at large and colonial Zimbabwe in particular. From the discussion it can be argued that there is an incomplete story on colonialism if white women are absent from the narrative of the colonial process. This has been shown through an examination of the contribution made to the war effort during in the Second World War by white women in Southern Rhodesian. As was the case during the First World War, there was an increased demand for women's labour outside the home. The war in 1939-1945 had a greater effect in this respect because of the wider participation of white women, including in the army itself.

It has been shown that the Second World War reconfigured, rather than assaulted, white women's domesticity which hitherto had confined them to the home front. Indeed, in spite of working outside the home, women remained influenced by the domestic ideology in the nature of their activities in the so-called public sphere. The services they rendered included voluntary work such as cooking, sewing, knitting and hospitality for the troops, among other activities. The impact of war on women's traditional roles as housewives elicited various responses from the women's organisations. While there were efforts to assist the women involved in the war effort, for example by providing day care for children, fears were raised about the perceived potential negative impacts of the changing roles and status of women. The paper has also given further evidence to support Cooper and Stoler's thesis on tensions of empire by examining the conflicts and tensions emanating from various efforts to harness white women's labour power. 